\title{
QUEEN'S
UNIVERSITY
BELFAST
}

\section{On the colonial frontier: gender, exploration and plant-hunting on Mount Victoria in early 20th-century Burma}

Johnson, N. C. (2017). On the colonial frontier: gender, exploration and plant-hunting on Mount Victoria in early 20th-century Burma. Transactions of the Institute of British Geographers, 42(3), 417-431.

https://doi.org/10.1111/tran.12176

\section{Published in:}

Transactions of the Institute of British Geographers

\section{Document Version:}

Peer reviewed version

Queen's University Belfast - Research Portal:

Link to publication record in Queen's University Belfast Research Portal

\section{Publisher rights}

Copyright (C) 2017 John Wiley \& Sons.

This work is made available online in accordance with the publisher's policies.

\section{General rights}

Copyright for the publications made accessible via the Queen's University Belfast Research Portal is retained by the author(s) and / or other copyright owners and it is a condition of accessing these publications that users recognise and abide by the legal requirements associated with these rights.

Take down policy

The Research Portal is Queen's institutional repository that provides access to Queen's research output. Every effort has been made to ensure that content in the Research Portal does not infringe any person's rights, or applicable UK laws. If you discover content in the Research Portal that you believe breaches copyright or violates any law, please contact openaccess@qub.ac.uk. 
This is the peer-reviewed version of the following article: Nuala $C$ Johnson, 'On the colonial frontier: gender, exploration and plant-hunting on Mount Victoria in early $20^{\text {th }}$ century Burma,' Transactions of the Institute of British Geographers (2017): This article may be used for non-commercial purposes in accordance with Wiley Terms and Conditions for Self-Archiving.

\title{
On the Colonial Frontier: Gender, Exploration and Plant-hunting on Mount Victoria in early 20th-Century Burma
}

\author{
Nuala C. Johnson \\ School of Natural and Built Environment \\ Queen's University Belfast \\ Belfast BT7 1NN \\ n.johnson@qub.ac.uk
}

\begin{abstract}
In April 1922 Charlotte Wheeler-Cuffe was elected a Fellow of the Royal Geographical Society. This honour was in recognition of her contribution to plant hunting and exploration, botanical illustration, and anthropological knowledge accumulated about Burma during the quarter of a century (1897-1922) she spent there with her husband as part of the colonial service. While historical geographers have acknowledged that the colonies, in particular, often afforded women the space for practicing science, the work of female naturalists in the field has received limited, detailed scholarly attention. For Charlotte Wheeler-Cuffe her plant-hunting expeditions across Burma allows us to extend the epistemic reach of a spatial perspective developed by geographers and demonstrates how the web of connections she developed in the colonies enabled her to circulate scientific knowledge across the globe. By focusing on a major expedition to Mount Victoria undertaken by Wheeler-Cuffe this paper unravels the complexity of the practice of natural history within a global imperial framework through an examination of the private correspondence and pictorial archive maintained during her time in Burma.
\end{abstract}

\section{Introduction}

"it is such a chance of seeing a lovely and little known part of the world, that I feel I should be a fool not to go".

This was the response of Charlotte Wheeler-Cuffe, to an invitation from the colonial

Commissioner's wife, Winifred MacNabb to undertake an excursion to Mount Victoria,

Burma in the spring of 1911. She had arrived in Burma in 1897 with her husband, Otway 
Wheeler-Cuffe, an engineer with the Indian Public Works Department, and they remained in colonial service there for the following 24 years. While resident in Burma Wheeler-Cuffe undertook a wide range of excursions around the country, both accompanying her husband in his professional capacity and also independently. She focused on accumulating knowledge of the natural history of the region, especially its plants, and making anthropological observations about the native peoples she encountered. As a consequence she produced scores of botanical illustrations of the flora of Burma, many of which she later donated to the National Botanic Gardens in Dublin; she collected new plant species; she circulated botanical material between Burma and home; she established a botanical garden in Maymyo; and she accumulated a range of geographical information about parts of the colony relatively unknown to Britons.

Historical geographers over recent years have persuasively argued that space and place are critical to understanding the constitution, production and circulation of science (Livingstone 2003; Livingstone and Withers 2011; Finnegan 2008). Focusing on the spaces in which scientific enquiry takes place they have demonstrated the significance of location and movement in the development of particular scientific knowledges (Naylor 2010; Veal, Enfield and Naylor 2014; Finnegan 2009). From the botanic garden to the laboratory; from the naturalist field club to the professional association; from the published treatise to the public lecture theatre, these studies have emphasized how scientific theories and practices were mediated through specific socio-spatial contexts which ultimately contributed to what was warranted as knowledge (Naylor 2002, 2007; Finnegan and Wright 2015; Withers and Keighren 2011). Concepts such as site, region, territory, boundary and mobility have animated this work resulting in a diverse variety of studies ranging in scale from the local and regional to the national and global (see Finnegan 2008 an overview). 
While these works have deepened the epistemic reach of a spatial perspective, Isla Forsyth $(2013,529)$ has built on these principles by suggesting that "The where of scientific practice at times was liberating, the colonies in particular affording women space for practicing science". Moreover feminist scholars have highlighted the role of Georgian and Victorian female naturalists in contributing to the production of scientific knowledge in their role as herbalists, collectors, physiologists and popularisers of floral and faunal knowledge (Shteir 1996). Of all the scientific fields open to women, (as well as to children and working class men), 'polite botany' afforded them perhaps the most promising outlet to pursue their scientific interests, as 'amateurs' were especially useful in supporting an increasingly professional discipline that largely comprised male practitioners (Allen 1994; Abir-Am and Outram 1987; Phillips 1990). Natural history was considered a "feminine science par excellence" (McEwan 1998, 219) as it provided women with the opportunity to discipline their bodies and minds through a regime of self-improvement practised outdoors, whilst also retaining their principal gendered responsibilities in the domestic sphere.

In the context of the colonies feminist geographers have assessed the relationships between gender and empire by focusing particularly on the work of female travel writers. Prompted initially by efforts to reposition women in the canon of Geography's histories (Domosh 1991; Rose 1993) further studies have highlighted the complex gender identities and attitudes underpinning the work of women who spent time in the empire as travellers, missionaries, and colonial wives. Eschewing essentialising versions of gender subjectivities these investigations have interrogated how questions of race and class as well as gender informed the work of prominent female travellers, like Mary Kingsley, and shaped their encounters with wider imperial projects (Blunt 1994; McEwan 2000). But travel itself was regularly contrasted with expeditionary science and its more explicit connections to individual heroism and discovery features which Blunt 
(1994: 32) contends construct "the overt masculinity of exploration and... [the] passive femininity of travel". While some privileged women attempted to move beyond this restricted version of their potential by challenging male authority and bringing their work to the attention of centres of scientific learning - for instance, Marianne North, Constance Gordon Cumming and Theodora Guest (Guelke and Morin 2001; Morin 1999) - these women might be seen as exemplars of exceptionality rather than part of a wider pattern of women engaging in science's production. Their social and familial status could, at times, help them to confront and overcome conventional divisions of labour, as with Marianne North who had the personal financial resources to travel extensively, to publish and to fund the establishment of a gallery at Kew to display her work.

By contrast Wheeler-Cuffe's work was translated primarily through the material artefacts she collected or produced in the colonies and in the private correspondence she maintained with family and friends rather than through published books or essays, or via the official documents of the colonial state. As Stoler (2010) has reminded us the gendered nature of the colonial archive obscures the active role of women in the colonies as producers of knowledge, and Saha $(2010,345)$ asserts that women's “agency has been subsumed to gendered archival and state practices". Moreover, where scientific knowledge is concerned, the valorization of texts over practices or objects may also conceal the contributions of women who did not have the means or desire to publish their work (Cooter and Pumfrey 1994). Unlike many official male plant-hunters of the nineteenth century who had their expeditions to the colonies supported by professional institutions or commercial nurseries women rarely enjoyed such sponsorship or imprimatur (Musgrave et al 1998). Consequently their work was often invisible in the official record and was only made transparent, if at all, when they produced published accounts of their discoveries. 
Moreover scholarship on women travellers tends to focus on the production and reception of their work at home, and the celebrity some achieved during in their lifetimes, thus downplaying the significance of long-term residence in shaping how science was produced and performed by women in colonies. In the case of Kingsley, Blunt (1994) argues that she negotiated between her private and public spheres differently between West Africa and home. Her opposition to women's suffrage and female membership of the RGS could co-exist with her more radical insights into the anthropology of West Africa, leading Maddrell (2009 84) to conclude that "Ambiguity best describes Kingsley's own attitude to her work and status, and her writing is riddled throughout with contradictory relationships between gender and colonialism". However Ciolkowski (1998) suggests that such gender ambiguities render Kingsley the model English woman, which she carefully cultivated over the course of her travels in Africa. Indeed she claims “The female traveler of Kingsley's text is a modern Britannia who, as ‘invincible global civilizing agent,' links symbolically the seemingly incompatible values of masculine strength and feminine moral leadership in the service of British imperial power” (Ciolkowski 1998: 349). Uncovering the 'hidden’ women of Geography animates Maddrell's (2009) magisterial overview of the contribution of female travellers, academics and educationalists to the development of Geography in Britain, and using a biographical framework, provides a basis for understanding the role of women in the construction of Geography's history. While she provides an extensive analysis of 'major' and 'minor' women who participated in the development of Geography's institutional apparatus (e.g. RGS; journal editors), those who largely operated outside such formal structures are marginal to the inquiry. I seek in this paper to reinstate the significance of a consideration of women who operated independently of formal disciplinary structures yet pursued their scientific interests vigorously in the field, and in this instance, in one of the remoter corners of empire. Thomas's (2007) embodied approach to investigating the 
wardrobe of Lady Curzon, Vicereine of India (1899-1905), shifted the emphasis from a textual to a material approach to understanding gender and empire, particularly from the perspective of a wealthy representative of the Crown in India. More broadly, focusing on the materiality of empire during long-term residency enables us to explore the experience through the practices of its colonial residents, and in this paper through their scientific work in natural history and art.

Building, therefore, on the insights provided by feminist geographers my focus will be on how the categories of masculinity and femininity were calibrated in the colonies when the practices of scientific knowledge-making are investigated.

Furthermore by examining the work of a woman who spent a quarter of a century in Burma and was not a well-known public figure like her contemporaries North, Bird, Curzon and Kingsley, we may begin to uncover the 'hidden' histories of empire's more 'ordinary’ residents. Charlotte Wheeler-Cuffe's relationship with empire may contrast with experiences and interpretations of transient travel writers who, with an eye on the home audience and the commercial potential of their observations, may have modulated their encounters with the colonies along different registers. The practice of being a plant collector, explorer, gardener and artist alongside the quotidian duties of the wife of a colonial official also marks out Wheeler-Cuffe as different to professional plantcollectors (female or male) sent from home to seek out botanical treasures. The focus on material and visual artifacts (plants and paintings), gathered or produced in situ, provides a different frame for understanding her knowledge-making activity than the work of travel writers whose texts were often ultimately produced, edited and distributed at home and for home consumption.

Wheeler-Cuffe's position as the wife of a colonial official enabled her to straddle the spaces of the public consort and the private resident, interacting with the officialdom of empire but also developing strong links with the indigenous population (servants, 
pupils in schools where she taught painting, guides, Burmese officials), upon whom she relied in various ways, to explore the colony's natural history. In this respect, her experience in Burma deviates from traditional historiographies which treat science in the colonies solely as a vehicle of imperial control (Harrison 2005). Kumar's (1995, vii) claim that "science and colonization can be precisely expressed through the term colonial science", has been challenged by a growing scholarly literature that stresses the complexity and unevenness of the interrelationships between metropole and colony and underscores the wider spatial turn in the histories of science (Endersby 2008, Tan 2004). The movement of science across space in the nineteenth century was, as historical geographers have proposed, neither unidirectional nor uniform (Withers and Livingstone 2011). Therefore to understand the natural history produced by Wheeler-Cuffe, and her position within the wider world, Ballintyne's concept of "webs of empire" $(2002,13)$ is more useful. The practice of science in the colonies, I suggest, was in dialogue with, rather than determined by, the science of the metropole. Through a complex network of connections Wheeler-Cuffe's knowledge about Burma's natural history was as much a product of her position as the wife of a colonial official with tight-knit connections in the colony, her relationship with the indigenous population, and her familial and professional contacts in Ireland and England, than as a consequence of any direct guidance provided by the imperial centre (Schiebinger and Swan 2007).

She was building on a long tradition of botanical collecting that had been expanding in the nineteenth century as the search for new exotic species and the desire to understand tropical nature deepened. Joseph Hooker's plant-hunting expeditions to the Himalayas stimulated professional interest in new species of rhododendrons and a burgeoning popular appetite for these new plants by gardeners and garden designers matched this. Their bold colours and vibrant flowers triggered a rhododendron craze and by the 1870s in British gardens they replaced American flora (Musgrave et al 1998). A 
popular thirst to increase the supply of other exotic species meant nurseries as well as professional botanists were actively seeking rare plants to enhance scientific understanding of tropical nature and to capitalize on the commercial opportunities of such new introductions.

Drawing on these new ways of thinking geographically about the production of science, this paper firstly seeks to analyse the practice of natural history in a particular type of colony. The experience in Burma differed to that of Britain's African possessions and even other parts of the British Raj in at least two ways. The state that was established by default in 1886 was an adjunct to the colonial regime in India. The Indian government paid the bills and the administration and bureaucrats required to run it were transported from India. And, unlike African colonies state-building was not a military affair in Burma. There was never a military governor. In contrast to its African possessions, Britain had no significant European competitors and thus did not have an equivalent foreign policy in this part of Southeast Asia. Instead a tried and tested system of administration was transferred from British India to Burma (Callahan 2003). The analysis will focus on one pioneering expedition made by Wheeler-Cuffe to Mount Victoria in the Chin Hills in 1911. This region represented a relatively unexplored territory on the colonial frontier between India and Burma. Since the end of the third Anglo-Burmese War (1885-86) there had been some limited missionary activity in the Chin Hills but there was no detailed knowledge of the natural history of the area developed by Europeans (Womack 2008). The region was topographically and ethnically different to Lower Burma, the area most inhabited by British colonists, and control over it was partial.

Secondly, this investigation seeks to deepen our understanding of the role of women in making botanical knowledge. Although feminist geographers have done much to unravel the complexities of women's experience of empire, and in particular have 
provided valuable insights into how gender shaped their travel-writing, my focus is explicitly concerned with the practice and translation of science by a long-term resident of Burma. Wheeler-Cuffe was elected a Fellow of the Royal Geographical Society in 1922, one year after her return to Ireland, and represents that coterie of women whose links to the RGS were a consequence of having travelled "with husbands or family on imperial duty" (Maddrell 2009, 55). Yet she succeeded in gaining some recognition for her scientific work, carried out on expeditions like the one to Mount Victoria. Moreover, unlike analyses of women travel-writers (Blunt 1994; Blunt and Rose 1994; McEwan 2000), her legacy resided not in published texts for consumption at home but in her plant illustrations, in the plants she collected and distributed, and in the work she carried out in the colony through establishing a botanic garden there (Johnson 2015). She was not constrained by having to offer public lectures or publish books when she arrived home, and therefore perhaps did not face the 'private-public' dualism emphasized in analyses of female travel writers. Moreover, unlike Lady Curzon or the wives of very senior colonial administrators, Wheeler-Cuffe could, to a large degree, avoid the spectacle of display associated with high office, and concentrate on her interests in botany, natural history and anthropology. By focusing on the practices of exploration undertaken by WheelerCuffe and the afterlife of her expedition to Mount Victoria we will appreciate more fully how gender shaped her experience. While Wheeler-Cuffe and MacNabb, on the surface, seemed to travel independently to one of colony's highest peaks, in reality their trip was constrained and circumscribed by the gendered context of exploring a frontier territory and their dependence on native Chins as well as Lower Burmese servants to assist in the physical as well as the intellectual journey (Blunt 1994; Emin-Tunc 2003).

Thirdly, taking as its starting point the recognition that science travelled across the empire through webs of connections rather than in a linear fashion from centre to periphery, I will argue that Wheeler-Cuffe's botany was a product of the linkages she 
formed in Burma as much as the networks she had cultivated at home. This follows Raj's (2007) rejection of diffusionist and indigenist models of scientific knowledge exchange, and his focus on the contact zones between Asian and European male scientists in South Asia where the knowledge was produced and circulated. These zones of contact, I suggest, also proved critical for women who sought to engage in science. Wheeler-Cuffe reached the summit of Mount Victoria with her female companion and a coterie of native assistants, she accumulated some important botanical and geographical information during the excursion, she gathered seeds and specimens of unusual plants, and she completed illustrations of the landscape and its flora. She transported this knowledge back to Rangoon and became the distribution node for its dissemination within Burma and across the ocean to home. Taking up Sivasundaram's (2010) challenge to put in place global histories of science which focus on interconnected rather than unilateral linkages I will highlight how a woman functioning outside the emerging 'canon' of female naturalists forged a significant assemblage of botanical materials which circulated between colony and home and provided some of the earliest (western) evidence about the natural history of the region. Her experience was inflected by the particularity of Burma within Britain's Indian empire, and reflects the local circumstances of that context.

\section{Situating Charlotte Isabel Wheeler-Cuffe (1867-1967)}

Charlotte Isabel Williams was born in Wimbledon on 24 May 1867. She was the granddaughter of the Reverend Sir Hercules Langrishe, third baronet of Knocktopher in Co. Kilkenny. She solidified her Irish connections by marrying Otway Wheeler-Cuffe in 1897. He was a nephew and heir of another baronet, Sir Charles Wheeler-Cuffe, of Leyrath, an estate three miles outside Kilkenny city which he would inherit during his tenure in Burma. She was therefore situated culturally and politically in a transitional space as nationalism and agitation for Home Rule gathered pace in Ireland while she 
served in the colonies. Otway Wheeler-Cuffe trained as a civil engineer at the Royal Indian Engineering College in Cooper's Hill, and, after marrying in 1897 he joined the Indian Public Works Department. They would spend following 24 years stationed in Burma and although they regularly made trips home to Kilkenny, Dublin and London, it was during this quarter of a century in Burma that she developed her skills in botanical collecting and illustration. Inspired by the landscape and flora she encountered she produced several hundred watercolour illustrations and on her permanent return to Ireland, she presented over 100 of them as well as the large personal correspondence she maintained with family and friends during her long residency in Burma to the Dublin botanic gardens. It is through this extensive manuscript and pictorial record that we can unravel the ways in which she accumulated and represented her geographical and botanical knowledge of the region. While there is no official record of her being formally trained in art, Nelson (2013) suggests that there is inferential evidence that she may have taken art lessons from William Frank Calderon, one-time Principal of the School of Animal Painting on London's Baker Street.

When Wheeler-Cuffe arrived in Burma in 1897 she was immediately enchanted by the place. Unlike images that suggested the tropics were debilitating and dangerous, especially for women, she was expressly energized by the experience (Stepan 2001). In her initial journey by steamer up the Irrawaddy to their first posting at Thyetmyo she enthused: "Such a river! Over a mile wide and a current like a millrace. Pretty steep wooded hills on the W. and lower ground with palm trees and rice fields on the E'. She later captured the allure of the scene in a small watercolour (Figure 1: From the flood gauge Thayetmyo 1900), an image which evokes the movement of this vast river and draws on the practice, developed in the eighteenth century, of using direct observation to represent encounters with new places (Clayton 2000). She communicated the vibrancy of the Irrawaddy by including the many Burmese riverboats, their colourful sails catching 
the breeze while a native observes the scene from the river's bank. The Irrawaddy was the principal conduit through which Burma's resources were transported for export to the port of Rangoon and through which British colonials travelled to Burma's interior. The iconic role of the river in the management of empire did not go unnoticed and the painting builds on the significance of eyewitnessing as an intrinsic component in establishing geographical knowledge, and detailed observation as the means of evoking the landscape visually (Stafford, 1984; Smiles 2000; Klonk's 1996). Upon her arrival at Thayetmyo she commented: "the place is charmingly pretty and [our] house though not actually on the river bank is not far behind. The ground all around the station is just like a very pretty park". She was also impressed by the supply of servants: "I have not clearly made out yet how many are servants and how many are 'hangers on', but there is about a dozen I think".

She adjusted quickly by meeting the Deputy Commissioner and his wife, and other residents. He immediately offered to help her make a garden of her 'compound', to domesticate the place she would now inhabit and to recognise her horticultural interests. The nice church, club and library of the settlement made her feel "so civilized" and marked her position as colonial resident accustomed to such emblems of civility. The fact that she was in a tropical climate did not, of course, go unnoticed and she remarked that the mosquitoes were terribly big "but they say one gets inoculated in time and the bites don't inflame as they do at first". ${ }^{2}$ She clearly regarded the Burmese tropics as a space in which she could acclimatize and not as pestilential zone that would damage her physical or moral well-being. Indeed during her regular furloughs back home she complained of the cool temperatures and looked forward to her return to the tropics. At the height of Britain's globalized empire Wheeler-Cuffe became intimately acquainted with Burma, and if as Baigent $(2014,39)$ suggests “The act of travelling, entering the public sphere in so manly a fashion, was still transgressive for a woman in 
the 1890s" she never shirked the challenge. She explored areas of the land relatively unknown to European botanists, but unlike the female travel-writers examined by geographers, Wheeler-Cuffe did not publish any of her findings. Instead she illustrated Burmese orchids as well as native rhododendrons, primulas and other species and built up a personal visual record of the region's botany (Nelson 1982). She rarely used pencil to outline her paintings and unlike professional botanical illustrators, her orchid studies are exemplars of painting directly from life in the field. She sketched plants in their natural habitats rather than denoting species to demonstrate their stamens, pistils, and seeds a technique often favoured by plant taxonomists (National Botanic Gardens 2002). While there has been some scholarly analysis of botanical illustration in general and of renowned illustrators this remains a relatively under-researched area of natural history (Brenan 1980; Ponsonby 1990; Losano 1997). Much of the existing work has taken an art history perspective documenting the changing styles over the centuries; the histories of particular publications like Curtis' Botanical Magazine; or the analysis of the private collections of notable naturalists (Noltie 2002; 2009). While watercolours were the preferred medium of botanical illustrators the renowned artist Marianne North represents something of an exception as she painted in oils. Her work is often interpreted through the lens of plant art rather than scientific illustration and unlike most 'amateur' artists her private wealth enabled her to publicly exhibit her work. By contrast Wheeler-Cuffe represents a coterie of women who could be described as the invisible workers, parallel to Shapin's (1994) 'laborants' in English scientific culture, women who did not enjoy sufficient credibility to warrant acknowledgment as active producers of knowledge, but who were important in the cumulative endeavour to understand the earth's biogeography.

\section{Prelude to Ascending Mount Victoria}


In early 1911 Wheeler-Cuffe declared to her mother that Winifred MacNabb, wife of the Deputy Commissioner, had invited her "to spend part of the hot weather up on Mt Victoria, the highest mountain in Burma... I'd sooner go there than to a 'civilized' place". ${ }^{3}$ She was referring to the high altitude hill stations, popular destinations during the hot season for colonials in the British Raj, with Maymyo, outside of Mandalay being the Burmese summer capital (Kenny 1995; Bhattacharya 2012). While Mount Victoria in the Chin Hills is not actually the highest peak in Burma at over 3,000 metres it was considered at the time to be amongst the highest in the land. The area had been originally surveyed and mapped around 1885 as part of the Survey of India, but Europeans rarely visited thereafter. In 1901-1902 Lieutenant H. Wood briefly examined its bird population (Wood and Finn 1902), and in 1904 Colonel G Rippon collected a large number of avian specimens, now held at the Museum of Natural History in Tring (Robinson et al 1998). Nelson claims that Wheeler-Cuffe was "undoubtedly the first person with botanical interests to visit the region, and she and Winifred MacNabb may also have been the first to record the place pictorially" $(2013,111)$. In Rangoon she was spending the spring providing drawing lessons for the girls in the local Burmese school and her paintings were also receiving some local acclaim as she had made $f 40$ from their sale over the previous year. $^{4}$

By February she had decided to accept the invitation, ${ }^{5}$ and the MacNabbs would be at Kampetlet, the military outpost in the Chin Hills, by the end of March. Mr Fell, the District Commissioner, and Captain Dawson of the Military Police, would be going up to inspect the district the first week of April and would accompany her there. ${ }^{6}$ Although she would have an escort the prospect of completing the journey without white colonial officials did not bother her. She opined: "So I shall be well looked after! Not that there is the smallest danger travelling in Burma. I would sooner travel alone here than in any country I know, especially in the jungle...there are thieves here as elsewhere, [but] an 
Englishwoman is about the least person they would attack knowing what a fuss would be made over it. One is as safe - or safer - on Mount Victoria as on Wimbledon Common". ${ }^{7}$ Her social status as the wife of a colonial official and her 'race', at least in her mind, insulated her from any dangers that might be present. Indeed the colonial state seemed to provide more protection than that enjoyed by women in Britain. Ironically though, Burma was not officially considered a very safe corner of Britain's empire (Bryant 2013). After 1896 the Chief Commissioner Charles Croswaithe, introduced the Indian system of local administration to Burma through the Village Act. This broke up the non-territorial ties of the indigenous social unit, the myo, and replaced them with the Indian territorially-based administrative unit of the village. This transformation of Burmese social structures ironically made the colony more dangerous (Cady 1958, Furnivall 1956), and paved the way towards a long-term pattern of "lawlessness and disorder" (Callahan 2002, 516). By the turn of the century Burma was considered the most dangerous place in the empire and Rangoon had the highest murder rate of any colonial city (Harvey 1946). While the colonial administration of Burma was, according to Callahan $(2002,522)$, a "skinny state, barely capable of keeping the trains running and collecting enough revenue to pay its police", when there were any challenges to it a coercive military response prevailed. For these reasons, and because Wheeler-Cuffe was to be accompanied by a military policeman, she may have felt secure. Moreover, British scholar-officials depicted Burmese women as freer and more independent than their Indian counterparts and characterized Burmese men as 'henpecked'. While the feminization of Burmese society served to "naturalise the rule of the masculine British" (Saha 2010, 354), this inversion of gender identities, by the colonial state, may have insulated Wheeler-Cuffe, in theory at any rate, from any acts of violence against her, and instill in her confidence about her status as a woman in this society. 
While the weather continued to be "wonderfully cool" in Rangoon, ${ }^{8}$ she eagerly planned her itinerary to Kampetlet. She would leave Rangoon by train on March $31^{\text {st }}$ to arrive at the town of Prome; from there she would take a mail steamer to Minbu. The Commissioner's launch would take her onward to Seikpyu and Captain Dawson would meet her to make the 70-mile trek to Kampetlet (Figure 2: Map of the Route). Colonel and Mrs. MacNabb would already be at the outpost and the Colonel would return to Seikpyu, leaving the two women with the Deputy Commissioner for the region. As it turned out her trip was delayed a week. At Minbu Colonel MacNabb who "had to hurry down as the high altitude upset him so" met her. While the thinner air of the Chin Hills challenged the Colonel, it presented no such fears in Wheeler-Cuffe. Captain Dawson and a few government survey schoolboys accompanied her on the steamer to Seikpyu and from there they began trekking to Kampetlet with pack mules. Wheeler-Cuffe also took two Burmans from home, her cook, Ko Pyaw whom she claimed was "an unknown quantity in the jungle" ${ }^{\text {"9 }}$ and her syce Maung Thet. Unlike the plant-hunting expeditions of Joseph Hooker or George Forrest her team of helpers was relatively modest. While they made the journey from the Irrawaddy (approximately 84 miles) under police escort, loaded initially with pack ponies, as the gradient got steeper they switched to mule packs. Of the journey upward she wrote, "The mule path was far harder going than the cart road and we faced up the hill in great style...Here and there a huge pine or rhododendron loomed out of the mist. Kampetlet stands on a great spur of the main mountain, which stretches down like a huge buttress, 5000 feet into the valley...Behind us rises Mount Victoria itself, but we cannot see the top as we are too much under it". ${ }^{10}$ Her letters were peppered with detailed descriptions of the trek upwards noting the geological terrain and plant life of the territory.

On arrival at Kampetlet, and despite the jungle environment she happily discovered two emblems of imperial rule - a telegraph and a post-office - each of 
which enabled her to maintain her web of connections between the Chin Hills, Rangoon, London and Kilkenny. She commented that Mrs. MacNabb "[is a] most kind and an interesting and well read woman, so that we have much to talk about, besides painting together". They stayed in the house of an old friend, Mr Nepean, who was the superintendent of the Pokokku Hill tracts and he had agreed to escort them on their climb to the top of the mountain which she noted "could not very well have been done alone". While both women were content to travel without their spouses the presence of some white male companion was deemed necessary for their ascent. She immediately began botanizing and delighted in the many plants they had discovered: the chief find is a sweet scented snow white rhododendron which grows like an orchid on other trees, never on the ground. I have got a lot of plants of it and will try to send some home. It does not seem to grow naturally below $7000 \mathrm{ft}$, so should be practically hardy...I think it should grow in moss and a little peat but no real earth. I don't think it is the same as any I have seen at home. Anyway it is very beautiful.

She sprinkled her account with reference to the potential hardiness of these species for growing in Britain. In addition she maintained a small sketchbook in which she produced a series of watercolours of the trip. In Figure 3 (Popa from Kampetlet May 1911), for instance, she depicted a small timber house in the foreground, with the mountainous landscape and the sacred site of Mount Popa occupying the middle distance. Using a panoramic lens she deployed the picturesque aesthetic beloved of landscape painters at home and used a colour palette dominated by mauves and lilacs to evoke the watery atmosphere of higher altitudes (Andrews 1989). While a panoramic perspective has been interpreted as a masculinist way of viewing, clearly for women artists too the appeal of a bird's-eye perspective is evident. Wheeler-Cuffe, however, does not just offer a single 
viewing position. In another watercolour (Figure 4: Kampetlet May 1911) she illustrates the route - a winding, narrow pathway, following the contours of the ridge - that leads up to the summit of Mount Victoria in the distance. Tall pines, as well as smaller shrubs and evergreen trees, convey altitude and contrast with the more luxuriant portrayals of tropical nature in other sketches she produced of Lower Burma. Loosely composed, and quickly executed, these landscape images lack the studied qualities of compositions produced by professional artist-travellers who accompanied official expeditions. They painted with a keen eye on the scientific and commercial value of their work (Bonehill 2014). Wheeler-Cuffe was not operating under those constraints and thus her images are often more intimate in scale and free in style, composed on site and reflective of her immediate reaction to a scene. Her enthusiasm for mountaineering contrasts sharply with Mary Kingsley's account of ascending Mount Cameroon where, according to Blunt (1994: 100) she "locates herself outside the masculine endeavor of mountaineering" and "describes the expedition as hard work rather than a source of pleasure" (103). WheelerCuffe wholeheartedly embraces the challenge of mountain climbing, and provides no evidence that she considers such endeavours solely the preserve of men. Indeed she finds such excursions enchanting, enervating and educational and rarely turns down an opportunity to engage in them.

She also provided commentary on the Chin tribes who occupied the region, and in this respect parallels with the practices of female travel writers to West Africa who regularly opined on the customs of the local people (Blunt and Rose 1994). She observed that the Chins "are the queerest little sturdy folk; very wild and uncivilized in some ways, but good humoured and nice in others, and friendly and cheery. The men wear little or no clothing except a strip of something around their heads with a feather stuck in it and the most minute loin cloth". By contrast the women "are bundled up in shapeless garments down to their knees and have their broad good humoured faces tattooed". 
Unlike her encounters with the natives of Lower Burma, the peoples of the Chin Hills are characterized through the vocabulary of the exotic and positioned within a temporal framework along an axis from tradition to modernity (Johnson 2014). Such an organizing principle enabled her to differentiate between the peoples of the frontier regions whose lives were much more remote from colonial administration from those areas where it penetrated most deeply. By contrasting the hill people to the Burmese she interacted with in Rangoon, she was providing a representation of regional differences and not treating the colony as a single, homogenous entity. Even though the unexplored Chin-Lushai hills were, for colonial rulers and missionaries, the "connecting link between their stations in Burma and India" (Pau and Bharati 2012, 14) for Wheeler-Cuffe the region's geopolitical significance was of less import than its biogeography. Observing, collecting and illustrating were all part of her botanizing endeavours and she was enchanted by the scene: "The cloud effects of light and shade rolling across the flanks of these great massive mountains are so wonderfully beautiful that I feel inclined to do nothing but sit and watch them all day". The physical geography of the region proved more alluring than its cultural contours and in a letter she included a sketch map which she claimed "is only a guess as I have no map which gives it here". ${ }^{11}$ Her cartographic and surveying skills had been honed over the decade she had spent in Burma accompanying her husband on many of his engineering projects. After their initial posting in Thayetmyo in 1898, for instance, she undertook a trip with Otway to Mindon 46 miles away, and assisted him in preparing the plans for a road-building project. She made a "a map of the whole road from here to Mindon, scale 1 inch to 1 mile" and although it was signed off by Otway "he said that my initials must go somewhere 'unbeknownst', so we put a lovely monogram at the end of the north point instead of the usual arrow points". ${ }^{12}$

\section{Ascending Mount Victoria}


If Mary Kingsley ascended Mount Cameroon in West Africa with some reluctance (McEwan 2000), Wheeler-Cuffe fully embraced the scientific and aesthetic appeal of climbing Mount Victoria. After a week botanizing around Kampetlet the party began their ascent and their entourage was an admixture of peoples, transport animals, food supplies, equipment and bedding. It included three pack ponies and about a dozen Chin coolies carrying their luggage. She described the coolies as "the weirdest, wildest looking folk you ever beheld", but recognized that enrolling their labour was central to their success. Using the indigenous population to assist in plant-hunting expeditions was common in Southeast Asia but the scale of operations was often larger (Fan 2004). For instance, expeditions led by Hooker or Kingdon-Ward could employ upward of fifty locals and this reflected their longer duration and more lofty ambitions. The WheelerCuffe group zigzagged across the spur on which Kampetlet was located until they reached the first crest [about 8,000 feet] of the long ridge that terminated with Mount Victoria. They were travelling through "evergreen forest...with patches of pine here and there. The ground clothed with wild strawberries in bloom and thickets of wild yellow raspberries and glades of bracken fern - Oak and Ilex, wild cherry and crimson tree rhododendron. In fact it is very like Woodstock on a very large scale”. Comparing new landscapes with home was a common familiarizing trope and as Arnold observes of India "the travelling gaze was to render the novel and exotic more familiar by attaching it to the cultural norms and epistemological systems of Western Europe while simultaneously emphasizing what was alien" (2006, 31). Wheeler-Cuffe periodically used the same organizing categories in her descriptions while at the same time providing descriptions of the flora that might be later useful as aides-mémoire when sent to centres of calculation at home.

Paths, developed by the local tribes, anchored the routes selected by Europeans to ascend alien and often unmapped territories (Hansen 1999; Endersby 2008; Martins 
2012), revealing yet again the ways in which western knowledge systems were moored to indigenous practices. In this expedition the following morning the two women rode their hired police ponies until the main path ended and they proceeded along foot tracks established by the Chins. For the final ascent to the summit the superintendent "rigged up a chair on poles for us, carried by four coolies, in case we could not take the ponies the whole way". While the superintendent may have regarded this gesture of transporting the women on improvised sedan chairs appropriate, both had extensive experience of trekking and had the requisite fitness and constitution for the final climb. They discarded their chairs after a few hundred yards, preferring to ascend on foot: "The first mile was up an open hill side, covered with bracken fern, primulas and blue gentian, with big pine trees here and there - then up a very steep, scrambly goat path with scrub jungle and thickets of tiny (and very prickly!) Scotch roses...Then along a scratch of a path a few inches wide, around a strip pine clad shoulder, rising on our right and across a saddle covered in more fern and gnarled tree rhododendrons". The terrain did not deter them and at $9000 \mathrm{ft}$ some of the red blossoms of tree rhododendrons observed earlier "still shone like great rubies against the sunshine". Wheeler-Cuffe recorded that the white flowering rhododendrons stopped at $8000 \mathrm{ft}$. They continued through dense forest until they reached an open area "dotted with the same red rhododendrons, here gnarled and twisted and stunted by the wind, and the most exquisite primrose yellow rhododendron, a low bush covered with great tresses of slightly sweet scented flowers which only seem to grow above 9000 feet". ${ }^{13}$ On the final saddle before the summit they stopped for breakfast. Providing detailed observations of the physical geography of the region and its plant life characterized her depiction of the ascent. She made a record that would be later useful for species identification, notably altitude, aspect and growing culture, and she resisted the temptation to interpret the area solely through the romantic lens beloved of travel writers. She observed that "The air was thin and cool and clear - we were just 
$10,000 \mathrm{ft}$ now and when the wind blew it was distinctly cold; (it freezes hard here in winter)".

On arriving at the summit she observed a rounded knoll "with one gnarled rhododendron on the side of it". It was the red-flowering species she had mentioned regularly during the ascent and in her watercolour it formed the focal point of the image (Figure 5: Summit of Mount Victoria, May 1911). The party gazed over miles of jumbled mountains in what she described as 'unadministered territory' where the 'wild' Chin tribes still raided one another. She claimed, however, that they are beginning to accede that they would be better off under the 'Pax Britannica'. Such judgments reflected the imperial milieu she inhabited and the social networks she maintained with Commissioners and others. She did not seem to doubt, in any significant way, the superiority of British administration over local styles of governance, and even though the Chin Hills were nominally under British jurisdiction, she was well-aware of the fragility of that authority in this frontier region. Thus while she had learned Burmese and appreciated the diversity of landscapes and cultures across Burma, she retained her belief in the positive disciplining effect of the regulation of affairs under colonial administration. The summit of Mount Victoria metaphorically marked that conviction.

However, natural history rather than explicit reference to the colonial relationship was the principal subject of her correspondence. On return to their bivouac she commented that they were "weary but triumphant, and laden with spoils". The vocabulary of achievement, reminiscent of sentiments expressed on expeditions conducted by men, is perhaps indicative of a shared rather than gendered sense of triumph expressed by Europeans who undertook these types of journeys. She had collected seeds of primulas, ranunculus, gentian, and plants specimens of orchids and rhododendrons. She intended to gift them to friends at Maymyo and Rangoon, and to send the remainder home to London and Kilkenny. ${ }^{14}$ On their descent she noted that the 
headman of each village came out to escort them so by the time they reached Seikpyu they numbered 25 people. This ritual reinforced, in her mind, their status as important visitors to the territory and bestowed upon them the approbation of village chiefs. It also of course, even in a frontier region, cemented the unequal power relations between native and colonial and one which was blind to gender difference. Once back in Rangoon she used her web of connections to dispatch samples of plants to friends and family in England and Ireland including "very large flowered white scented Rhododendron[s], which grow on other trees like an orchid; [they] would do in pots with lots of drainage and moss and a little leaf mould or peat, and quite tiny plants bloom". She also sent some orchids, including the "flame coloured"15 Dendrobium anachinides and she reminded her mother to distribute some of the rhododendron plants to Leyrath. Intoxicated by the trip she mused: "How I wish you could see them in their wild state; I have never seen anything so lovely". ${ }^{16}$ Wheeler-Cuffe was careful about the logistics of transporting plants across the ocean and in a note the following day she warned her mother that there was a little, cardboard box "of tiny precious orchids" 17 in the consignment.

\section{Mount Victoria - Afterlife}

The plants arrived safely in Leyrath and Baroness Prochazka sent some of them to the Dublin botanic gardens which became the conduit through which these species were propagated and distributed to other botanical institutions and into private gardens. Nelson claims that these "represent the earliest collection from Kew as far as can be determined" (Nelson 2013, 111), and thus perhaps confirms her as the first European to provide detailed knowledge of this region's natural history. Wheeler-Cuffe also sent pressed and dried specimens directly to Kew with detailed descriptions of the habitat in which she collected them. She was well aware of the advantages of providing illustrations, live specimens, seeds and descriptions for accurate scientific identification. 
While this first visit did not yield any published reports, it laid the foundation for a second trip the following year. In the interim she met the plant-hunter George Forrest in Rangoon and showed him some of the plants collected in 1911 and he assured her that, from his experience, the yellow-flowering rhododendron was a new species. Her local networks in Burma were important in facilitating her work and after the 1912 trip she sent plants to Sir Frederick Moore, the Director of Dublin's botanic gardens. She included more examples of the yellow and white-flowering rhododendrons and a drawing of the latter which "grows epiphytically on other trees of any sort". She also included seedlings of the red tree rhododendron and claimed that "the plants have got rather mixed, as I had only one afternoon to collect them, \& one Chin Cooly who only spoke very little Burmese, to carry them" ${ }^{18}$ Keeping order on her collection in the field was more difficult when local labour was limited. In a characteristic self-deprecating turn - one often repeated by female explorers - she yielded to the superior wisdom of the professional male plant-hunter. Adopting such a modesty trope is reflected in her claim: "I am unfortunately very ignorant about botany, though I love plants; but Mr Forrest tells me that the Chin Hills have never been worked out botanically, \& therefore any specimens from there would be of interest" (Nelson 1982, 35). Her attitude reinforces Blunt's (1994: 36) claim that the tone of professionalism and scientific accuracy of male explorers contrasted "with the more self-conscious tone of many women travel writers in the perceived need to vouch for scientific accuracy". While Wheeler-Cuffe adopts a deferential posture in her correspondence it is, I contend, a strategic move to secure cooperation from professionals at home rather than indicative of any deeply held belief. Her long self-education in botany, watercolour painting and gardening, ensured that she was extremely well-informed on these matters, and mirrors the skills of many upper-class women of the period, who although amateur in status, had become accomplished plant collectors and naturalists (Shteir 1996; Sheffield 2001, Naylor 2007). Moreover, Moore, 
a great orchid enthusiast, warmly received the specimens and commended her paintings as "very beautiful and very accurate". ${ }^{19}$ Securing his imprimatur was important for her long-term links with the garden, and from his perspective, cultivating contact with her was critical as a future source of rare species that would enhance the reputation of his institution.

The plants were treated with great care in Glasnevin and in 1914 Moore sent some to Kew for identification and where the power to name officially resided. He informed Wheeler-Cuffe that two new species of rhododendron had been identified (Nelson 1982). The R. cuffeanum was named and attributed to her and her painting of this plant reflects the style and skill of illustration she had developed over years in the field (Figure 6). Rather than using a technique which meticulously detailed individual leaves, flowers, stamens, and fruit — a style popular with professional illustrators — she adopted a naturalistic approach that focused on the plant's natural habitat attached to the bark of the host pine (Blunt and Stearn 1993). Using a loose style of composition she exposes the flowers' stages of development from bud to opened bloom. Director of Kew, Sir David Prain wrote to Moore confirming that the plant was new and it appeared in Curtis's botanical magarine in August 1917. The plant's epiphytic habit, delineated clearly by Wheeler-Cuffe in her painting was not mentioned and the locality in which it was found was incorrectly attributed. The yellow species, also provided by her, was named Rhododendron burmanicum, and was described in the Kew bulletin in 1914. Ironically, however, this species did not become widely known until it was collected by KingdonWard in 1956 and when it became the parent for many scented yellow hybrids developed thereafter. Kew's botanist R.A. Rolfe identified a small orchid she also collected as the species Ione flavescens and the blue 'buttercup', which Wheeler-Cuffe described as growing prolifically as an Anemone, as Anemone obstusiloba f. patula. It was illustrated by Matilda 
Smith in Curtis's botanical magazine in 1915 (Nelson 1995; 2013). Together the relatively short and small expedition to Mount Victoria yielded some significant finds.

\section{Conclusion}

Charlotte Wheeler-Cuffe achieved much during her quarter century in Burma. She painted the landscape and plants she intensively observed during her time there. She explored relatively uncharted territories, often in the company of other colonial wives. She developed strong links with the botanic gardens in Dublin, supplying them with seeds, new plant species, dried specimens and pictorial illustrations of what she observed. She initiated and became central to the circulation of plant knowledge about Burma in a period when its biogeography was not well known and she used her artistic skills to translate that knowledge. With no formal training in either botany or art, she acquired her knowledge in the field and used the expertise of others when available and when necessary. Acknowledging that travel writers like Bird and Kingsley and artists like North did travel alone in Africa, Asia and America, Wheeler-Cuffe's position as the wife of a colonial official allowed her extended access over a long period of time to a range of places otherwise relatively inaccessible to a white, European woman in Burma. And even in the case of travel writers, particularly Kingsley, Ciolkowski (1998: 344) has demonstrated that the long partnership between empire and travel is ever-present “despite the persistently critical perception that Kingsley's gender places her somehow above or outside the structures of imperial possession". Wheeler-Cuffe never seemed to place herself outside of the colonial world she inhabited with her husband, but she did recognize her capacity to engage in some greater scientific endeavours than she might have done had she remained at home.

We can draw some broader conclusions from this analysis about the making of natural history knowledge in the colonies during the late nineteenth century. Firstly, historical geographers have paid little attention to the role of botanical illustration and 
plant hunting in the accumulation and dissemination of scientific knowledge, and although these themes have been examined from other disciplinary perspectives, it is notable that natural history, one of the primary arenas of scientific investigation in which women played significant roles, has not received greater attention by geographers. While there has been an explosion of studies on the role of written texts, publishing regimes, speech spaces, and societies in the production of geographical and natural history learning, there has been less attention devoted to visual reproduction and the collecting practices that enabled new species to circulate around the globe (Naylor 2010; Finnegan 2009; Withers 2010; Livingstone 2007; Ogborn and Withers 2010). The expeditions of Wheeler-Cuffe partly fill those lacunae in our understanding of how botanical knowledge was materially accumulated and circulated, particularly in the case of Burma whose natural history was less well understood at the imperial centre than other parts of British India. Secondly, although feminist scholars have highlighted the significance of gender in our thinking about the construction of empire, not many historical geographies have engaged with the contribution of women to science in an imperial context. Most studies have focused on women travellers whose interests were more cultural and religious than scientific; on the visual spectacle of empire; or on the gendered domestic arrangements of imperial households. This is partly due to absences in the colonial archive which primarily documents the policies and activities of male administrators. It is also a product of much scholarly work on expeditionary science focusing on major explorations orchestrated, funded and led from the centre. In the late nineteenth century women were rarely leaders in such enterprises and consequently they found themselves often excluded from being the attributed producers of scientific work (Livingstone and Withers 2011). Yet botanical drawing and plant collecting were spheres in which they did play significant roles and Wheeler-Cuffe, although not carrying the professional credentials of many of her male counterparts, was one such contributor. 
Thirdly, not only did Wheeler-Cuffe actively paint in the field and record the species she observed, she also became a supply line for plants to be transported from the colonies to the metropole. Unlike those constrained by the commercial and ideological imperatives of official explorations orchestrated from Britain her long residency in Burma enabled her to build up a significant network of contacts and to develop some personal local prestige as an expert on the colony's plant geographies. This paper has recognized that Wheeler-Cuffe's plant-hunting and ethnological expeditions required the mobilization of a web of connections that included colonial officials and inhabitants of the colony as well as native agents (Driver 2013; Sivasundaram 2010). Her experiences challenge a conceptual framework for understanding the relationship between science and empire that would characterize that relationship as unidirectional or linear. The particular gendered context in which she lived necessitated her building up networks within the colony that would enable her to explore and collect. Ultimately the accumulation and circulation of knowledge was as much a product of Wheeler-Cuffe's networks within Lower and Upper Burma as any of her connections with home. She was neither a professional plant-hunter nor colonial botanist sent from Britain. Notwithstanding the social conventions in which she worked she proved to be remarkably adaptable and flexible across a variety of spheres of expertise from sketching and plant collecting to designing a botanic garden. Her capacity to produce botanical work outside the normal channels underscores the significance of the locally produced grid of social and spatial relationships she had cultivated in Burma that enabled her to transmit biogeographical knowledge about the colony across the globe.

\section{Acknowledgments}

Many thanks to David Livingstone and Máirín Nic Eoin for their constructive advice and encouragement on an earlier version of this paper. I owe a debt of gratitude to the very 
generous and helpful comments of Simon Naylor and the anonymous reviewers, and to Fiona Nash for overseeing the paper through the editorial process. All errors remain mine alone.

${ }^{1}$ Letter from Wheeler-Cuffe to her Mother, Kokine, March 5 1911. National Botanic Garden Archive, Glasnevin, Dublin (hereafter NBG)

2 All preceding quotes from: Letter from Wheeler-Cuffe to Mother, July 28 1897, Thayetmyo. NBG.

${ }^{3}$ Letter from Wheeler-Cuffe to her Mother, Kokine, January 9 1911. NBG.

${ }^{4}$ Letter from Wheeler-Cuffe to her Mother, Kokine, January 31 1911. NBG.

${ }^{5}$ Letter from Wheeler-Cuffe to her Mother, Kokine, February 6 1911. NBG.

${ }^{6}$ Wheeler-Cuffe spelled the military outpost Kampetlet although it is conventionally spelled Kanpetlet. In this paper I will deploy her usage apart from in the map in Figure 2.

${ }^{7}$ Letter from Wheeler-Cuffe to her Mother, Kokine, February 26 1911. NBG.

${ }^{8}$ Letter from Wheeler-Cuffe to her Mother, Kokine, March 5 1911. NBG.

${ }_{9}$ All preceding quotes from: Letter from Wheeler-Cuffe to her Mother, SS Bandit on the Irrawaddy April 13 1911. NBG.

${ }^{10}$ Letter from Wheeler-Cuffe to her Mother, Kampetlet, April 20 1911. NBG.

${ }_{11}$ All preceding quotes from: Letter from Wheeler-Cuffe to her Mother, Kampetlet, April 27, 1911. NBG.

12 Letter from Wheeler-Cuffe to her mother, Thayetmyo, August 21, 1898, NBG.

${ }^{13}$ All preceding quotes from: Letter from Wheeler-Cuffe to her Mother, Kampetlet, May 5, 1911. NBG.

${ }_{14}$ All preceding quotes from: Letter from Wheeler-Cuffe to her Mother, near Kampetlet, May 9, 1911. NBG.

15 All preceding quotes from: Letter from Wheeler-Cuffe to her Mother, Kokine, May 22, 1911. NBG.

${ }^{16}$ Letter from Wheeler-Cuffe to her Mother, Kokine, May 28, 1911. NBG.

${ }^{17}$ Letter from Wheeler-Cuffe to her Mother, Kokine, May 29, 1911. NBG.

18 All preceding quotes from: Letter from Wheeler-Cuffe to Sir Frederick Moore, June 8, 1912. NBG.

${ }^{19}$ Letter from Sir Frederick Moore to Wheeler-Cuffe August 12, 1912. NBG.

\section{References}

Abir-Am P G and Outram D eds 1987 Uneasy careers and intimate lives: women in science 1789-1979 Rutgers University Press, New Brunswick NJ

Allen D E 1994 The naturalist in Britain Princeton University Press, New Jersey

Andrews, M 1989 The search for the picturesque Standford University Press, 1989

Arnold D 2006 The tropics and the travelling gaze: India, landscape, and science, 1800-1856 University of Washington Press, Seattle

Baigent E 2014 Travelling bodies, texts and reputations: the gendered life and afterlife of Kate Marsden and her mission to Siberian lepers in the 1890s Studies in Travel Writing 18 34-56

Ballantyne T 2002 Orientalism and race: Aryanism and the British Empire Palgrave, Basingstoke 
Bhattacharya N 2012 Contagion and enclaves: tropical medicine in colonial India Liverpool University Press, Liverpool

Blunt A 1994 Travel, gender and imperialism: Mary Kingsley and West Africa Guilford Press, London

Blunt A and Rose, G eds 1994 Writing women and space: colonial and postcolonial geographies, Guilford Press, London.

Blunt W and Stearn W T 1993 The art of botanical illustration Collins Antique Collectors Club, London

Bonehill, J 2014 'New scenes drawn by the pencil of truth': Joseph Banks' northern voyage Journal of Historical Geography 43 9-27

Brenan J M P 1980 A vision of Eden: the life and work of Marianne North Holt, Rinehart and Windston, New York

Brockway L H 2002 Science and colonial expansion: the role of the British Royal Botanic Gardens Yale University Press, New Haven

Cady J 1958 A bistory of modern Burma Cornell University Press, Ithaca NY

Callahan M P 2002 State formation in the shadow of the Raj: violence, warfare and politics in colonial Burma Southeast Asia Studies 1 513-36

Callanan M P 2003 Making enemies: war and state building in Burma Ithaca: University of Cornell Press

Ciolkowski L E 1998 Travelers' Tales: Empire, Victorian Travel and the Spectacle of English Womanhood in Mary Kingsley's "Travels in Africa", Victorian Literature and Culture 26 337-366

Clayton, D W 2000 The creation of imperial space in the Pacific Northwest Journal of Historical Geography 26 325-350

Cooter R and Pumfrey S 1994 Separate spheres and public places: reflections on the history of science popularization and science in popular culture History of Science 32 237-67

Domosh M 1991 Towards a feminist historiography of geography Transactions of the Institute of British Geographers 16 95-104

Driver F 2013 Hidden histories made visible? Reflections on a geographical exhibition Transactions of the Institute of British Geographers 38 420-35

Emin-Tunc T 2003 Gender and imperialism Women's Studies Quarterly 31 316-19

Endersby J 2008 Imperial nature: Joseph Hooker and the practices of Victorian science University of Chicago Press, Chicago

Fan F-T 2004 British naturalists in Qing China: science, empire and cultural encounter Harvard University Press, Cambridge MA

Finnegan D A and Wright J J eds Spaces of global knowledge: exbibition, encounter and exchange in an age of empire Ashgate, London 
Finnegan D A 2009 Natural history societies and civic culture in Victorian Scotland Pickering and Chatto, London

Finnegan D A 2008 The Spatial Turn: Geographical Approaches in the History of Science Journal of the History of Biology 41 369-388.

Furnivall J S 1956 Colonial policy and practice: a comparative study of Burma and Netherlands India New York University Press, New York

Guelke J K and Morin K M 2001 Gender, nature, empire: women naturalists in nineteenth century British travel literature Transactions of the Institute of British Geographers 26 306-26

Hansen P 1999 Partners: guides and Sherpas in the Alps and Himalayas, 1850s-1950s in Elsner J and Rubié J P eds Voyages and visions: towards a cultural history of travel Reaktion, London 210-31

Harvey G E 1946 British rule in Burma 1824-1942 Faber and Faber, London

Forsyth I 2013 The more-than-human geographies of field science" Geography Compass 7 527-39

Harrison M 2005 Science and the British empire Isis 96 56-63

Johnson N C 2015 Global knowledge in a local world: Charlotte Wheeler Cuffe's encounters with Burma 1901-1902 in Finnegan D A and Wright J J eds Spaces of global knowledge: exbibition, encounter and exchange in an age of empire Ashgate, London 19-38

Johnson N C 2014 Botanical travel, climate and David Moore's moral geographies of Europe Journal of Historical Geography 44 122-132

Kenny J 1995 Climate, race and imperial authority: the symbolic landscape of the British hill station in India Annals of the Association of American Geographers 85 694-714

Klonk, C 1996 Science and the perception of nature: British landscape art in the late eighteenth and early nineteenth centuries Yale University Press, New Haven

Kumar D 1995 Science and the Raj: a study of British India Oxford University Press, Oxford

Livingstone D N and Withers C W J 2011 Geographies of nineteenth-century science Chicago University Press, Chicago

Livingstone D N 2007 Science, site and speech: scientific knowledge and the spaces of rhetoric History of the Human Sciences 20 71-98

Livingstone D N 2003 Putting science in its place: geographies of scientific knowledge Chicago University Press, Chicago.

Losano A 1997 A preference for vegetables: the travel writings and botanical art of Marianne North Women's Studies 26 423-48

Maddrell A 2009 Complex locations: women's geographical work in the UK 1850-1970 Wiley-Blackwell, Oxford

Martins L 2012 Geographical exploration and the elusive mapping of the Amazon Geographical Review 102 225-44

McEwan C 2000 Gender, geography and empire: Victorian women travellers in Africa Ashgate, Farnham 
McEwan C 1998 Gender, science and physical geography in nineteenth century Britain Area 30 215-23

Midgley C 1998 Gender and imperialism Manchester University Press, Manchester

Morin K 1999 Peak practices: Englishwomen's 'heroic' adventures in the nineteenth century American West Annals of the Association of American Geographers 89 489-514

Musgrave T, Gardner C and Musgrave W 1998 The plant hunters: two bundred years of adventure and discovery around the world Ward Lock, London

National Botanic Gardens 2002 Plant treasures: two hundred years of botanical illustration from the National Botanic Gardens, Glasnevin National Botanic Gardens Glasnevin, Dublin

Naylor S 2010 Regionalizing science: placing knowledges in Victorian England Pickering and Chatto, London

Naylor S 2007 Provincial authorities and botanical provinces: Elizabeth Warren's 'Hortus Siccus of the Indigenous Plants of Cornwall' Garden History 35 84-95

Naylor S 2002 The field, the museum and the lecture hall: the spaces of natural history in Victorian Cornwall Transactions of the Institute of British Geographers 27 494-513

Nelson C E 1982 The Lady of the rhododendrons - Charlotte Wheeler Cuffe 1867-1967 Rhododendrons 33-41

Nelson C E 1995 The art of flowers... botanical illustrations by Wendy Walsh and Charlotte Wheeler Cuffe Stationery Office, Dublin

Nelson C E 2013 Shadow among splendours: Lady Charlotte Wheeler-Cuffe's adventures among the flowers of Burma 1897-1921 National Botanic Gardens Glasnevin, Dublin

Nolte H J 2000 The Dapuri drawings: Alexander Gibson \& the Bombay botanic gardens Antique Collectors' Club, Edinburgh

Nolte H.J 2009 Raffles' ark redrawn: natural history drawings from the collection of Sir Thomas Stamford Raffles The British Library and Royal Botanic Garden Edinburgh, London

Ogborn M and Withers C W J eds 2010 Geographies of the book Ashgate, London

Pau P K and Bharati V 2012 Rethinking religious conversion: missionary endeavor and indigenous response among the Zo (Chin) of the India-Burma borderland Journal of Religion and Society 14 1-17

Phillips P 1990 The scientific lady: a social history of women's scientific interests 1520-1918 Weidenfeld and Nicolson, London

Ponsonby L 1990 Marianne North at Kew Gardens Webb and Bower, Exeter

Quilley G 2014 Introduction: mapping the art of travel and exploration Journal of Historical Geography 43 2-8

Raj K 2007 Relocating modern science: circulation and the construction of knowledge in South Asia and Europe, 1650-1900 Palgrave Macmillan, Basingstoke 
Robinson C R, Buck H, Farrow D S, Fisher T and King B F 1998 A birdwatching visit to the Chin Hills, West Burma, (Myanmar), with notes from nearby areas Forktail 13 109-120

Rose G 1993 Feminism and geography: the limits of geographical knowledge University of Minnesota Press, Minneapolis

Saha J 2010 The male state: colonialism, corruption and rape investigations in the Irrawaddy delta c. 1900 Indian Economic and Social History Review 47 343-76

Schiebinger L and Swan C eds 2007 Colonial botany: science, commerce and politics in the early modern world University of Pennsylvania Press, Philadelphia

Shapin $\mathbf{S} 1994$ A social history of trutb: civility and science in seventeenth-century England University of Chicago Press, Chicago

Sheffield S L-M 2001 Revealing new worlds: three Victorian women natualists Routledge, London

Sivasundaram S 2010 Introduction: global histories of science Isis 101 95-97

Shteir A B 1996 Cultivating women, cultivating science: Flora's daughters and botany in England, 1760-1860 Johns Hopkins University Press, Baltimore

Smiles S 2000 Eye witness: artists and visual documentation in Britain 1770-1930 Ashgate, Aldershot

Stafford B M 1984 Voyage into substance: art, science, nature and the illustrated travel account, 1760-1840 Harvard University Press, Cambridge MA

Stepan N L 2001 Picturing tropical nature Reaktion, London

Stoler A 2010 Along the archival grain: epistemic anxieties and colonial common sense Princeton University Press, New Jersey

Thomas N 2007 Embodying imperial spectacle: dressing Lady Curzon, Vicereine of India 18991905 Cultural Geographies 14 369-400

Veal L, Enfield G and Naylor S 2014 Knowing weather in place: the Helm Wind of Cross Fell Journal of Historical Geography 45 25-37.

Withers C W J and Keighren I M 2011 Travels into print: authoring, editing and narratives of travel and exploration, c 1815-c.1857 Transactions of the Institute of British Geographers 36 560-573.

Withers C W J 2010 Geography and science in Britain, 1831-1939: a study of the British Association for the Advancement of Science Manchester University Press, Manchester

Wood H and Finn F 1902 On a collection of birds from upper Burma Journal of the Asiatic Society of Bengal 71 121-131

Womack W 2008 Contesting indigenous and female authority in the Burma Baptist Mission: the case of Ellen Mason Women's History Review 17 543-559 


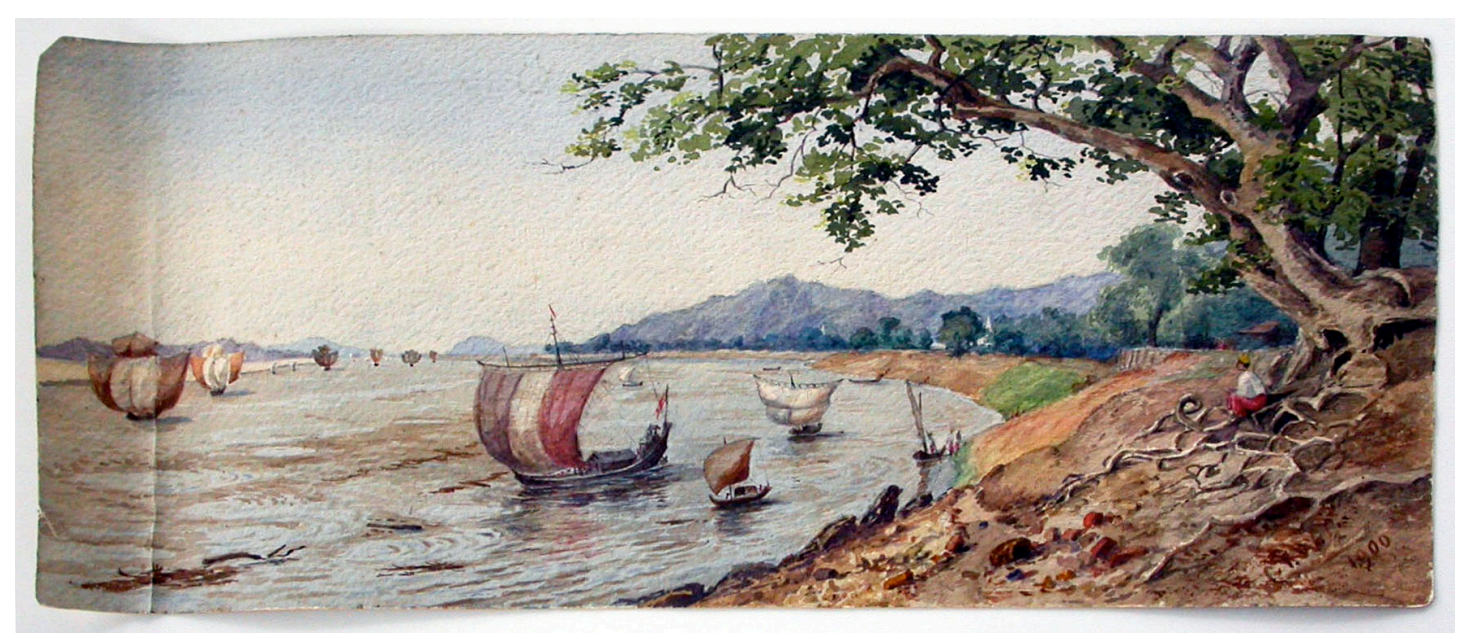

Figure 1: From the flood gauge, Thayetmyo 1900 (Courtesy of the National Botanic Gardens, Glasnevin) 


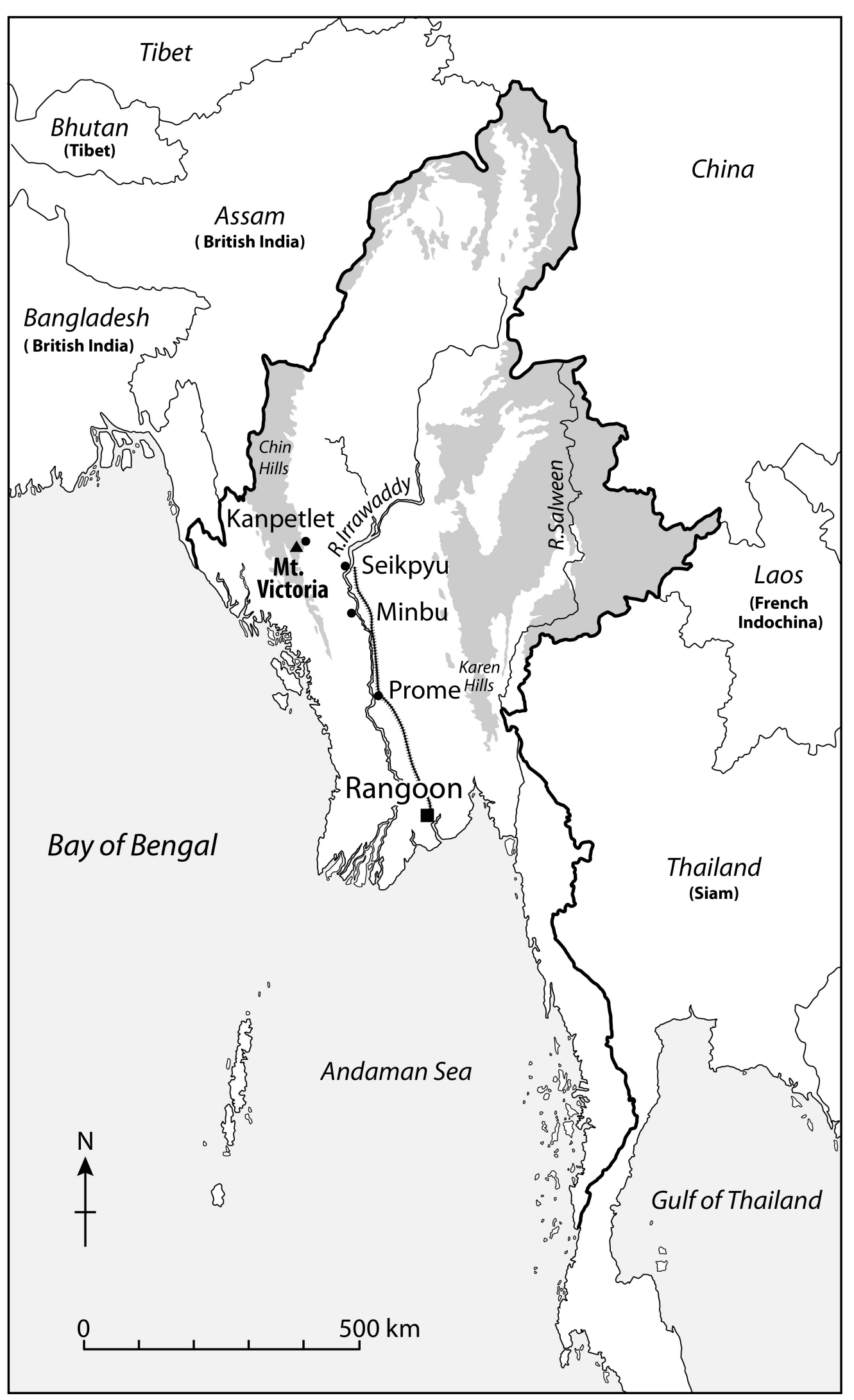

Figure 2: Map of the route 


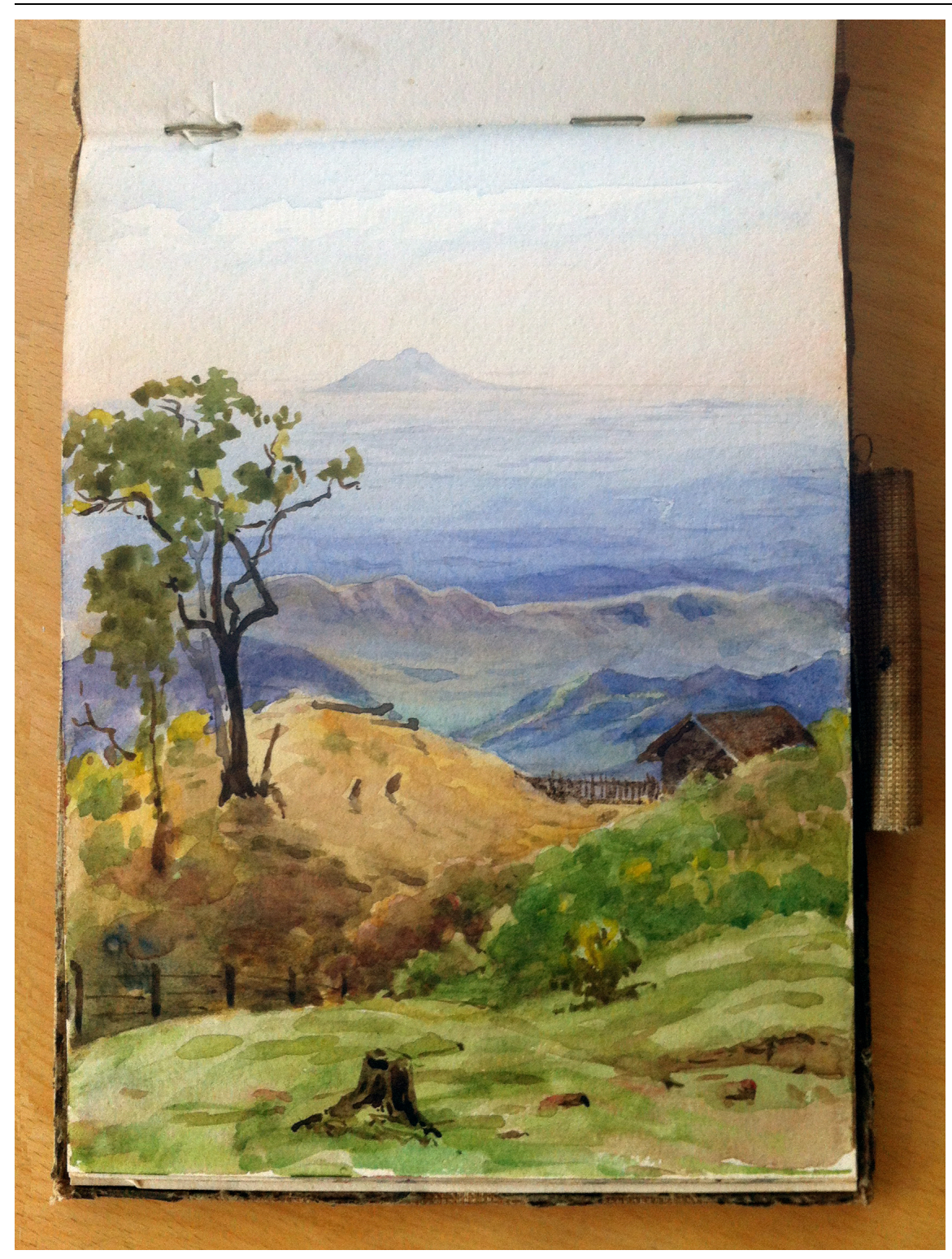

Figure 3: Popa from Kampetlet, May 1911 (Courtesy of the National Botanic Gardens, Glasnevin) 


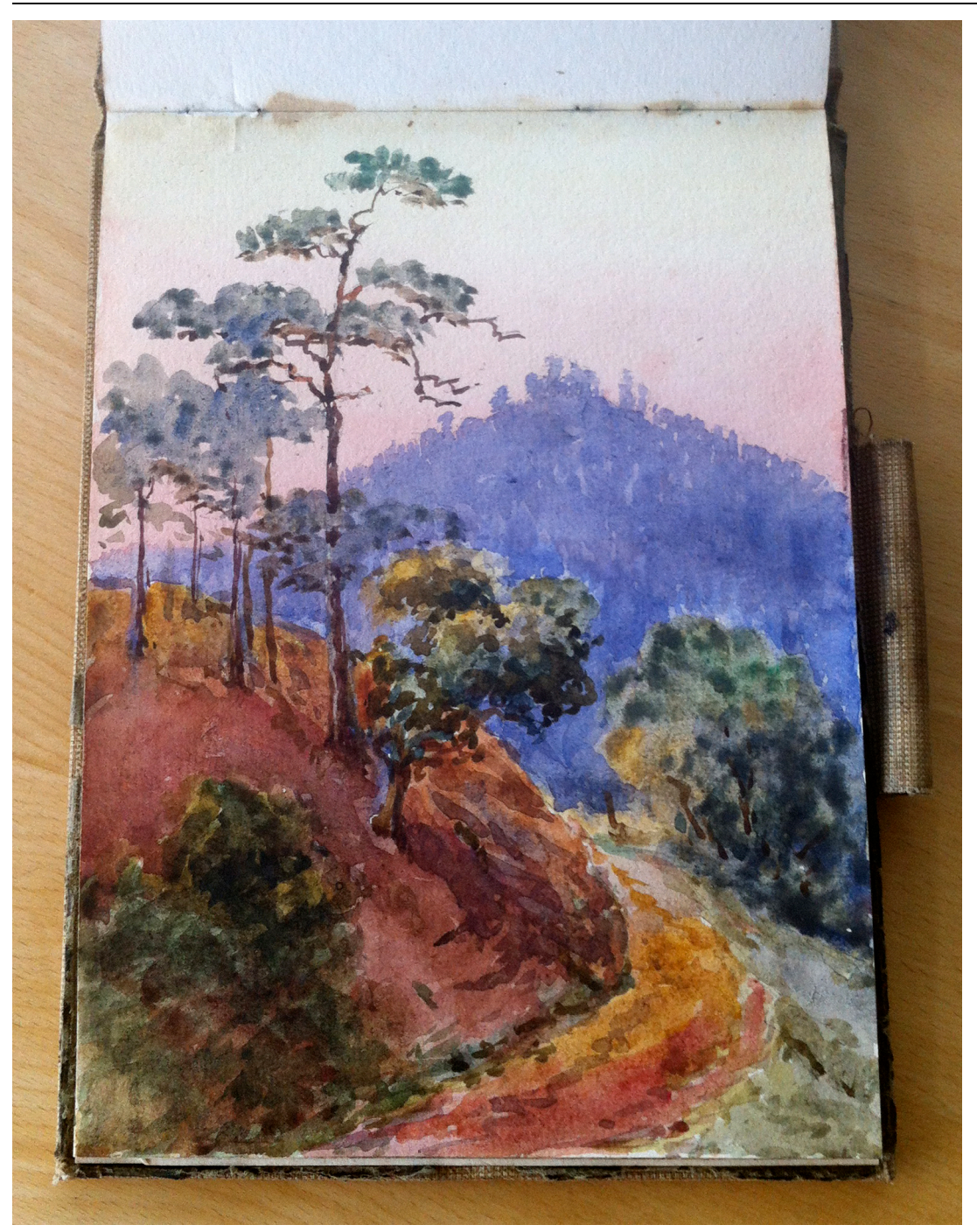

Figure 4: Kampetlet, May 1911 (Courtesy of the National Botanic Gardens, Glasnevin) 


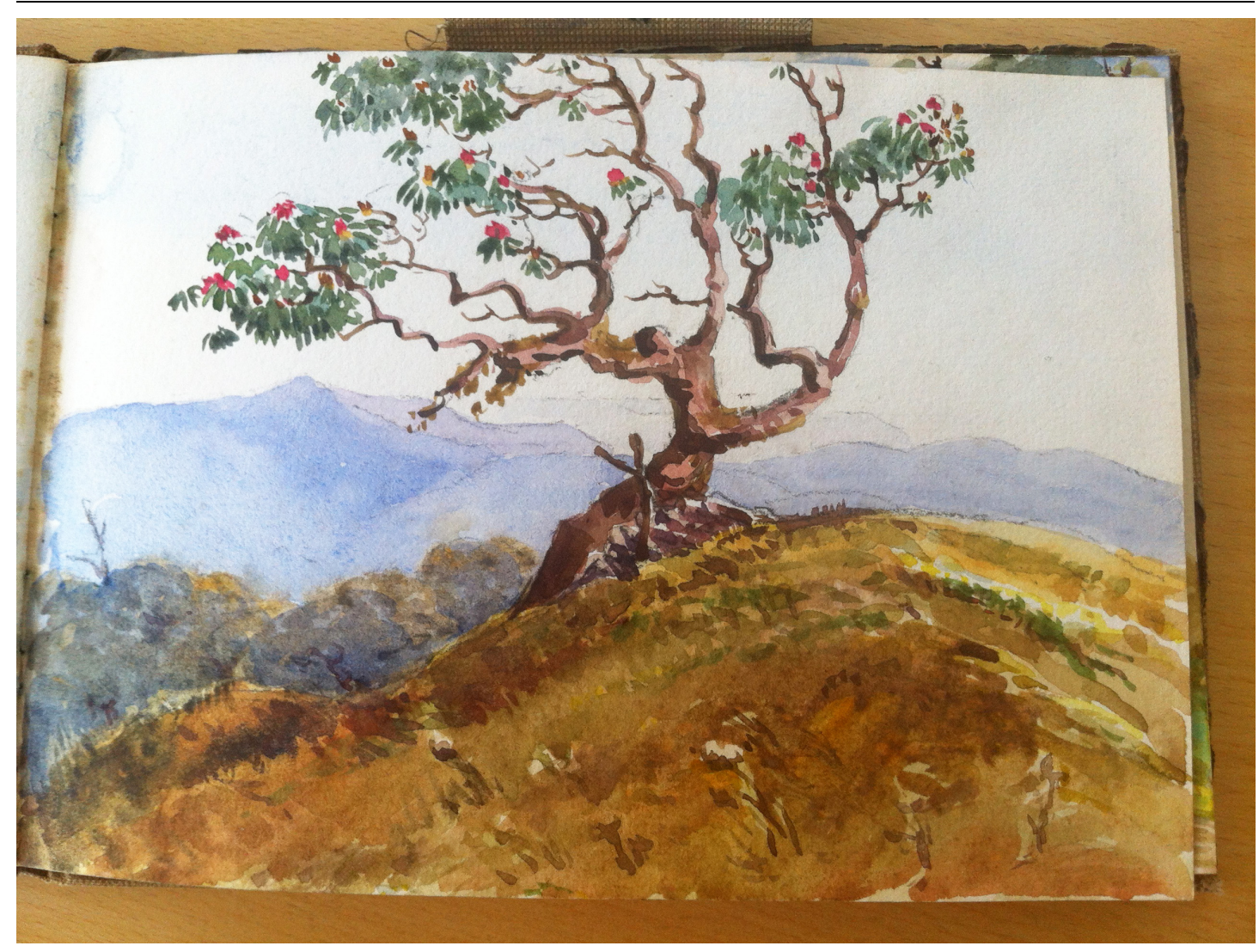

Figure 5: Summit of Mount Victoria, May 1911 (Courtesy of the National Botanic Gardens, Glasnevin) 


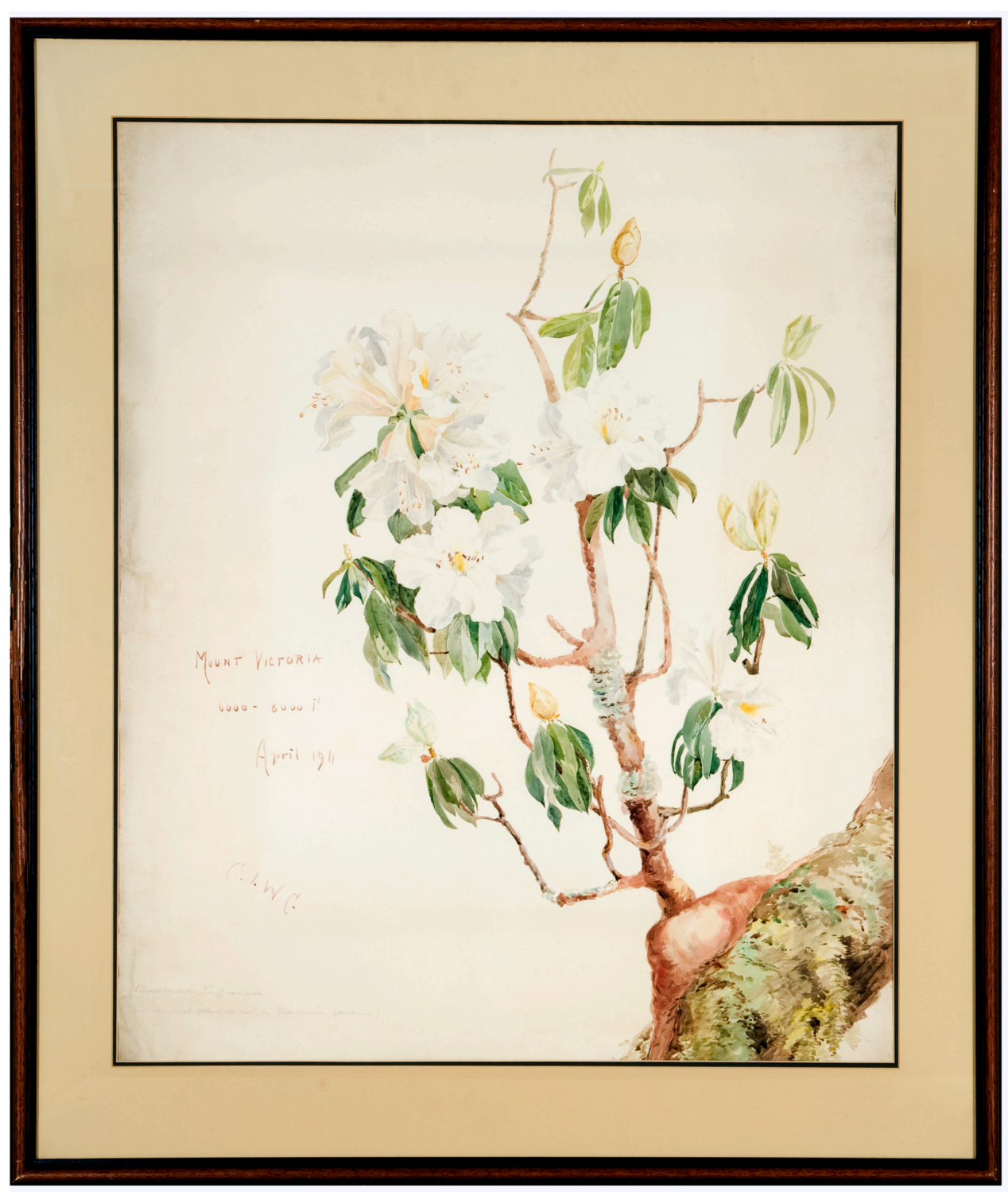

Figure 6: Rhododendron cuffeanum 1911 (Courtesy of the National Botanic Gardens, Glasnevin) 